特 集 $3^{*}$

\author{
消化器外科と Septic shock一とくに血行動態より \\ みた病変と治療 \\ 福島医大第 1 外科 \\ 元木 良一
}

\title{
SEPTIC SHOCK: HEMODYNAMICS AND TREATMENT
}

\section{Ryoichi MOTOKI}

First Surgical Department, Fukushima Medical School, Fukushima

索引用語: Septic shock, ショックの血行動態, ショック治療

\section{I はじめに}

急性化膿性汎発性腹膜炎に代表される重症感染症にお。 いても, 治療の基本は化学療法と, 切開排膿などの外科 手術療法である．これらの治療法が奏効するまでには若 干の時問が必要で, この間に, 患者が循環不全すなわち ショッッから離脱できずに死亡する場合るあるし，幸シ ョックから離脱できてる，ショック状態が獣延した場合 は長時間の臟器潅流低下による二次的な臟器機能不全を 来して死の転帰をとる場合もある.

抗ショック療法と呼ばれる各種治療法の目的はこのよ うな死を防ぐことにあり, 循環系からのそれは重症感染 によってもたらされた循環系の機能低下を早期に正しく 捕えて各種手段で補助することにある.

\section{II 研究対象ならびに方法}

教室では重症患者の治療に際しては Swan Ganz catheter を挿入, 留置して, 血行動態の推移をみながら管 理しているが，このようにして管理した重症感染26例を 対象とした.

Swan Ganz catheter の挿入, 留置, 測定, 各種測定 値よりの計算法についてはすでに度々報告してきた通り である ${ }^{12)}$. 血行動態の図示は教室で工夫した方法によ ったが，図1に示す如く，測定あるいは計算した各值を 放線状に配列した直線上にプロットした. 円との交点が 各値の正常值である. 図はほぼ正常の血行動態の 1 例を

* 第15回日消外会総会シンポ 1 消化器外科と感染
因 1 血行動態図示法

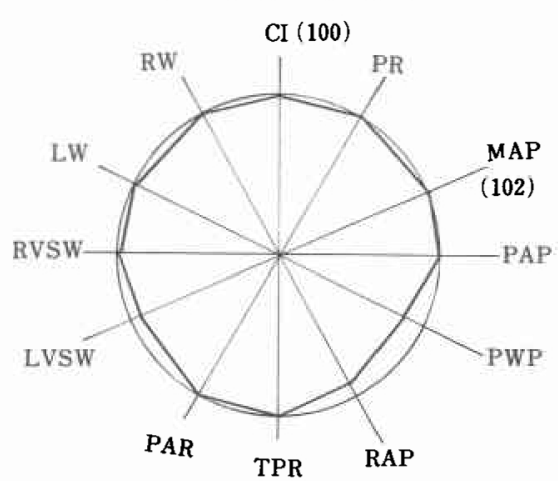

$\mathrm{CI}=$ 心指数, $\mathrm{PR}=$ 心拍数, $\mathrm{MAP}=$ 動脈圧, $\mathrm{PAP}=$ 肺動脈王, $\mathrm{PWP}=$ 肺動脈揳入匠, $\mathrm{RAP}=$ 右房王, $\mathrm{TPR}=$ 全末梢血管抵抗, $\mathrm{PAR}=$ 肺小動脈抵抗, $L V S W=$ 左室一回拍出仕事量, RVSWI=右室一回拍 出仕事量, $L W=$ 左室分時仕事量, $R W=$ 右室分時 仕事量

各值をつらねた型が円型に近ければ, 各值が正常値 であることを意味し，血行動熊が正常であると判定 できる. 因は正常の 1 例. 示す.

\section{III 成楼ならびに分析}

\section{1. 心指数の推移と治療成綪}

術前, 術直後, 術後24時間, 術後48時間の各期に打け る心指数と転㷌を図 2 亿示す.

術直後に正常心指数を示した症例は 1 例のみであっ た。一般外科症例では約 $1 / 3$ が術直後に於いても正常流 量を示すという松井の ${ }^{3)}$ の成績と比較し，重症感染症は 
図 2 心指数の推移々転㷌

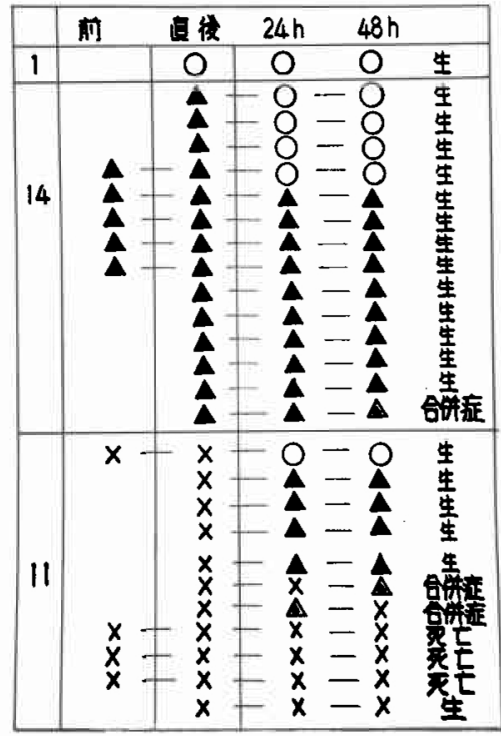

$\mathrm{O}=$ 正常型, $\Delta=$ 高流量, 低 PWP $\Delta=$ 高流量, 高 PWP,$\times=$ 低流量

循環系の影響が大きいものと考えられた。

術直後に高心指数あるいは低心指数を示していたすの でも，術後48時間までに正常心指数に回復した症例は全 例生存しており，治療に際しては正常心指数への復㷌を 目標に治療すべきことを示唆していた。

高心指数例中，肺脈梁入圧 (Pulmonary wedge pressure, 以下 PWP) が低値を示した症例（図中黒ぬり三 角）は良好な転帰を示したのに対し，PWP が高值を示 した症例（図中二重三角）は高率に合併症を来したこと から，これら 2 者は区別して考えなければならない病態 でありとくに後者では合併症防止に留意すべきことを 示していた.

低心指数症例 は PWP の高低にかかわらずいずれる 予後不良で，低心指数状態が 48 時間以上遷延した症例の 成績は不良であった。

\section{2. 高心指数应例}

高心指数を示した症例は PWP 值の高低により，低 PWP と高 PWP に分類された.

（1）高心指数，低 PWP

この血行動態の特接は，1）心指数の上昇，2）動脈 圧の低下，3）肺動脈楔入圧（左房圧を反映）の低下， 右房圧の低下，4）血管低抗の低下などであった。

この血行動態はいわゆる hyperdynamic 型と呼ばれる
図 3 高流量, 低 PWP 例 42才, 男, 胆管炎

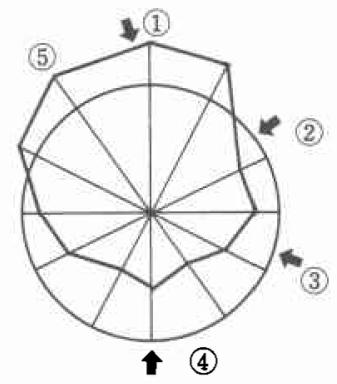
1. 心指数 $\uparrow$
5. 心仕事量 $\uparrow$
2. 動脈圧
3. 心房圧
4. 血管抵抗

もので, 教室で行った動物実験による分析では(4)，こ の病態の primary の変化と目されるのは，AV シャン トあるいは血管拡張による血管抵抗の低下で，これを代 償して, 心指数や心仕事量が増加しているすのと解され た. 換言すれば，高心指数は良好な循環を表現するもの ではなく，破綻寸前の循環系が辛うじて代償されている 姿と考えられた。

したがって,このよらな病態に対処するには補液, 輸 血などで充分に血管床を満たし，強心剤の投与が必要と なる．血管床の状態が回復するにしたがい，時に水分過 剩の傾向が出現するので場合よっては利尿剤の投与を考 慮すべきである。

（2） 高心指数, 高 PWP

この血行動態が hyperdynamic 型と異なる点は高 PWP および高右房圧である点で, hyperdynamic 型が 相対的な hypovolemia なのに対して overhyarationを 示していた。感染症による心不全傾向を背景に過剰補 液, 腎不全, などよる循環血液量の過剰を反映してい るものと解された。

前述したようにこの病態は合併症なかでも肺合併症 と密接な関係があった. 合併症発現によって PWP が 上昇した可能性も否定できないが，臨床的には PWP をモニターしながら患者を管理し，PWP 上昇時には利 尿剂，補液制限などが有効な手段であった。

\section{3. 低心指数症例}

低心指数症例では PWP の低值のものと高値のもの の 2 型があった。

（1）低心指数, 低 PWP

心指数の低下，動脈圧の低下，心房圧の低下，血管抵 
図 4 低心指数例
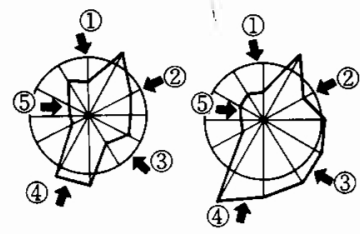

1. 心指数

1. 心指数

2. 動脈压 $\downarrow 2$. 動脈压

3. 心房圧 3. 心房圧

4. 血管抵抗 $\uparrow 4$. 血管抵抗 $\uparrow$

5. 心仕事量 $\downarrow 5$. 心仕事量

左は hypovolemia，右は心不全，同一症例であ る. 56 才, 女, 汎発性腹膜炎, 左の状態から輸 液，輸血を行い6 時間後に右となる。

抗の上昇, 心仕事量の低下を示し, hypovolemia による 心指数の低下と考えられた，術直後低心指数を来した11 例中10例は hypovolemia 型を呈した。重症感染症では 局所的因子として渗出, 浮腫, 出血なと，全身因子とし て経口㩑取量減少，不感蒸泄増加などにより hypovolemia を招き易い状態にあるため高率に合併したものと解 された。

（2）低心指数，高 PWP

心指数の低下，動脈圧の低下，心房圧の上昇，血管抵 抗の上昇, 心仕事量の低下を示し，心不全による心指数 の低下が考兄られた図4 .

これら 2 型の間には移行するむのがあり，低心指数症 例では多かれ少なかれ hypovolemia と心不全傾向を共 有するむのと考えられた。すなわち, hypovolemia の改 善には輸血，輸液による volume expansion が有效の筈 であるが，図4 に示す如く，同じ症例で輸血，輸液後に 心不全型に移行するものが認められた。

図 5 は低流量症例の心機能の 推移をみたものである が, 症例によっては, 輸血, 輸液が PWP（左房圧之考 えてよい）の上昇のみをもたらし，左室一回拍出仕事量 の増加につながらぬものがあり，このような症例では 低心機能状態にあるため, 盲目的な輸血, 輸液はPWP を高め肺合併症, 肺浮腫の発現を早める結果となる点に 注意すべさである。

これらの症例では適正な体液管現とともに強心剤, 血 管作働剂を投与して心拍出量を増加させ，血管低抗を低 下させることが必要となる。

このような見地からステロイド投与，扣よびイノバン の投与を好んで用いているが，図6にそのようにして管 理した代表的症例を示す.
表 1 Hyperdynamic state の意義

\begin{tabular}{|c|c|}
\hline 有藏 & 事卧成秘 \\
\hline 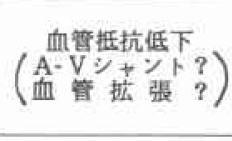 & 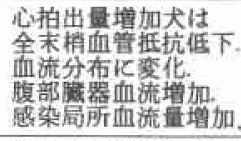 \\
\hline 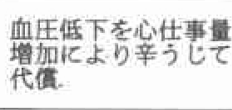 & 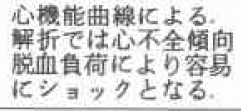 \\
\hline
\end{tabular}

図 5 低心指数例心機能の推移太線は心不全傾 向症例

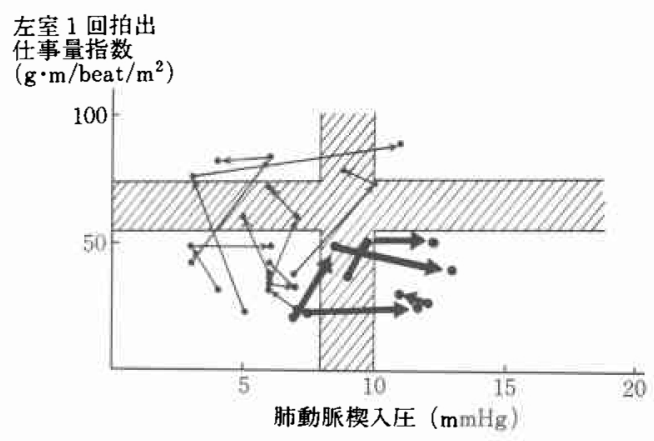

図 6 低心指数症例

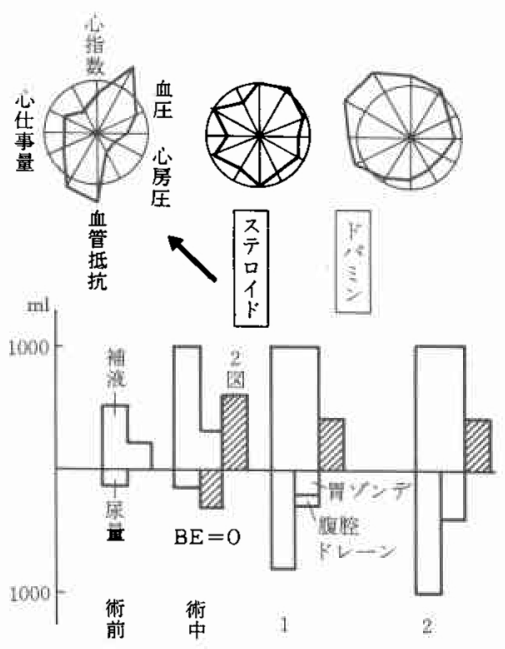

症例は73歳, 男性.S 字状結腸癌穿孔による急性汎発 性腹膜炎で, 術直後 SGC を挿入して測定したところ, 低心指数であることが判明，輸血，輸液，ステロイド投 与を行い,その後ドパミンの特続点滴注入によって心機 能改善と利尿をみ，全治せしめ得た。

IV 結 語

術前後にわたり Swan Ganz catheter を挿入留置して 
管理した重症感染症26例の血行動態を分析した. 重症感 染症では正常の血行動態を維持するるのは少なく, hyperdynamic 型, overhydrtaion 型, hypovolemia 型, 心 不全型など各種の異常な血行動態が出現した. 各々の病 態を分析し，それに対応すべき治療法について述べた。

\section{考安文缡}

1）元木良一ほか：外科疾患患者管理飞おける flow directed catheter の意竞. 日外会誌, 78: 148-161, 1977.
2) 元木良一注か：Swan Ganz カテーテルの応用. 踽外, 34:63-70, 1979.

3）松开隆夫：一般外科疾患に於ける術前術後血行 動態に関する研究。福島医誌, 29 : 95一111, 1979.

4) 元木良一, 永索 : Septic モデル犬の作成法 とついて. 日外会誌, 75：731-737, 1974.

5) 永笔 堯: Septic shock, 特 $K$ hyperdynamic state に於ける血流分布の变化. 福島医誌, 23 : 61-66, 1978. 